\title{
Effect of Make A Match Learning Model on Student Learning Outcomes on Statistical Materials
}

\author{
${ }^{1}$ Nurfiati, ${ }^{2}$ Vera Mandailina, ${ }^{3}$ Mahsup, ${ }^{4}$ Syaharuddin, ${ }^{5}$ Abdillah, ${ }^{6}$ Eka Fitriani \\ ${ }^{1}$ SDN Impres Wonto Bima \\ 2.3.4.5Pendidikan Matematika Universitas Muhammadyiah Mataram, Indonesia \\ ${ }^{6}$ Universitas Muhammadiyah Mataram \\ 1nurfiati@gmail.com, 22Vrmandailina@gmail.com, ${ }^{3}$ supyeka@gmail.com, \\ 4syaharuddin.ntb@gmail.com, 5abdillah.ummat@gmail.com, ekaabata88@gmail.com
}

\section{ARTICLE INFO}

\section{Article History:}

Received : 10-03-2020

Revised : 15-04-2020

Accepted : 21-05-2020

Online : 30-05-2010

\section{Keywords :}

Learning Outcomes;

Make A Match model.

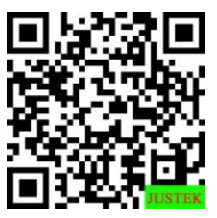

\begin{abstract}
Abstract: The lowest average daily repeat score data is 65 and has not met the minimum completed criteria of 75. The Make a Match model is very helpful in creating an effective learning environment by utilizing the elements that exist in students. This learning model is a game in the form of question cards and answer cards. The purpose of the study was to determine the influence of the Make a Match learning model on students' math learning outcomes. The research design is quasiexperimental with post-test only. Sampling using random sampling method was taken as many as 2 classes as control class and experimental class. Hypothesis testing used t-test, calculation result obtained t-count of 1,688 while t-table value of 1,645, because t_hitung $>$ t_(table) then $H_{-} O \mathrm{O}$ rejected and hypothesis received. It is concluded that there are differences in learning outcomes between the control class and the experimental class. It is recommended that teachers can continue to develop the Make a Match model.
\end{abstract}

Abstrak: Data nilai ulangan harian siswa rata-rata paling rendah yaitu 65 dan belum mencampai kriteria ketuntasan minimal yaitu 75 . Model Make a Match sangat membantu menciptakan lingkungan belajar yang efektif dengan memanfaatkan unsur-unsur yang ada pada siswa. Model pembelajaran ini berupa permainan berbentuk kartu soal dan kartu jawaban. Tujuan penelitian untuk mengetahui pengaruh model pembelajaran Make a Match terhadap hasil belajar matematika siswa. Rancangan penelitian adalah quasi eksperiment dengan post-test only. Pengambilan sampel menggunakan cara random sampling diambil sebanyak 2 kelas sebagai kelas kontrol dan kelas eksperimen. Pengujian hipotesis digunakan uji $t$, hasil perhitungan diperoleh t-hitung sebesar 1.688 sedangkan nilai t-tabel sebesar 1.645 , karena $t_{\text {hitung }}>t_{\text {tabel }}$ maka $H_{O}$ ditolak dan hipotesis di terima. Disimpulkan terdapat perbedaan hasil belajar antara kelas kontrol dengan kelas eksperiment. Disarankan guru dapat terus mengembangkan model Make a Match. 


\section{A. LATAR BELAKANG}

Pendidikan adalah usaha sadar terencana dan sistematis yang bertujuan untuk mentrasnfer ilmu pengetahuan kepada orang lain (Mahsup \& Anwar, 2020). Dalam kehidupan manusia, pendidikan sangatlah penting karena pendidikan merupakan salah satu kebutuhan manusia untuk mengembangkan potensi yang di milikinya yang dijadikan sebagai bekal hidup sekarang maupun yang akan datang (Mandalina et al., 2019)(Muhardini et al., 2020). Oleh karena itu, pendidikan itu sendiri bertujuan untuk mengembangkan potensi yang ada dalam diri manusia (Mahsup \& Anwar, 2018)(Eka Fitriani, 2018). Sebagaimana yang dikemukakan dalam Undang-Undang Nomor 20 Tahun 2003 tentang Sistem Pendidikan Nasional, Pasal 1 ayat 1 menyatakan bahwa pendidikan adalah usaha sadar dan terencana untuk mewujudkan suasana belajar dan proses pembelajaran agar peserta didik secara aktif mengembangkan potensi dirinya untuk memiliki kekuatan spiritual keagamaan, pengendalian diri, kepribadian, kecerdasan, akhlak mulia, serta keterampilan yang diperlukan dirinya, masyarakat, bangsa dan negara. Namun untuk mewujudkan hal tersebut di atas, tentu diperlukan suatu proses dan upaya kerja keras yang sejalan dengan sistem pendidikan nasional (Habe \& Ahiruddin, 2017)(Mahsup, 2018).

Sehubungan hal di atas, pelaksanaan pendidikan yang berlangsung dalam upaya mencapai tujuan pendidikan sebagaimana yang dimaksud tersebut di atas masih mengalami kendala terutama masalah kualitas (Alawiyah, 2017)(Arta Diantoro et al., 2019). Salah satu kendala yang dialami dalam upaya peningkatan kualitas pendidikan di sekolah tersebut adalah pada pendidikan matematika (Budi, 2012)(Mahsup et al., 2020). Sejauh ini pembelajaran masih didominasi oleh pandangan bahwa pengetahuan sebagai fakta untuk dihafal (Rahmatin et al., 2019)(Mahsup et al., 2018). Pembelajaran tidak hanya difokuskan pada pemberian pembekalan kemampuan pengetahuan yang bersifat teoritis saja akan tetapi bagaimana agar pengalaman belajar yang dimiliki peserta didik itu senantiasa terkait dan mampu meningkatkan hasil belajar peserta didik itu sendiri (Sukri \& Purwanti, 2016)(Mandailina \& Mahsup, 2018).

Guru sebagai pendidik merupakan pencipta kondisi belajar siswa yang didesain secara sengaja, sistematis, dan berkesinambungan (Kabunggul et al., 2020)(Muhardini et al., 2020). Sedangkan siswa sebagai peserta didik pembelajaran merupakan pihak yang menikmati kondisi belajar yang diciptakan (Yusup, 2017)(Mahsup \& Anwar, 2017). Belajar merupakan kegiatan yang kompleks (Sintayana Muhardini, Sukron Fujiaturrahman, 2018). Hasil belajar berupa kapabilitas, setelah belajar orang memiliki keterampilan, pengetahuan, sikap, dan nilai timbulnya kapabilitas tersebut adalah dari stimulasi yang berasal dari lingkungan dan proses kognitif yang dilakukan oleh pembelajar (Mandailina et al., 2019). Dengan demikian belajar adalah seperangkat proses kognitif yang mengubah sifat stimulasi lingkungan, melewati pengolahan informasi menjadi kapabilitas baru (Mahsup \& Abdillah, 2019).

Berdasarkan hasil wawancara atau observasi peneliti pada guru matematika di SMP N 19 Mataram kelas VII mengatakan bahwa sebagian besar siswa ditemukan di dalam 
kelas masih bermain waktu belajar dan kadang siswa mengalami kesulitan memahami konsep matematika dan hasil pembelajaran masih kurang atau tidak efektif sehingga mengakibatkan hasil belajar siswa kurang memuaskan. Terutama pada materi statistika siswa masih kurang paham dalam menyelesaikan masalah atau cara menyelesaikan rata-rata hitung, sejauh ini siswa mengalami suasana pembelajaran menjadi tidak kondusif sehingga siswa menjadi pasif dan pembelajarannya dikelas menjadi tidak optimal. Hasil belajar matematika tidak hanya dipengaruhi oleh kurangnya penguasaan terhadap materi tetapi juga disebabkan oleh beberapa hal, diantaranya kurang variatif guru dalam penyampaian pembelajaran matematika (Aini et al., 2019).

Dalam penyajian pembelajaran guru masih menggunakan model pembelajaran konvensional yaitu model pembelajaran yang biasa dilakukan guru secara terus menerus yaitu pembelajaran yang masih terpusat pada guru.Langkah-langkah pembelajaran yang dilakukan guru adalah menyiapkan kelas, memberi motivasi, menyajikan materi, memberikan contoh soal, kemudian siswa mencatat, dan setelah itu memberikan latihan-latihan soal yang terdapat pada buku paket yang disediakan oleh sekolah. Rendahnya daya analisis peserta didik dibuktikan dengan rendahnya hasil penilaian kognitif ulangan akhir semester ganjil kelas VII B dan VII D sebagaimana tercantum pada Tabel 1.

Tabel 1. Nilai Kognitif Siswa

\begin{tabular}{cccccc}
\hline \multirow{2}{*}{ No } & \multirow{2}{*}{ Kelas } & \multicolumn{2}{c}{ Jenis kelamin } & Jumlah & Nilai rata- rata \\
\cline { 3 - 4 } & & $\mathrm{L}$ & $\mathrm{P}$ & & \\
\hline 1 & VII B & 16 & 15 & 31 & 63 \\
\hline 2 & VII D & 17 & 13 & 30 & 68 \\
\hline
\end{tabular}

Berdasarkan Hasil ulangan harian peserta didik khususnya pada Kelas VII dengan nilai rata-rata masih di bawah 65. Padahal batas Kriteria Ketuntasan Minimal (KKM) peserta didik adalah 75. Untuk mengatasi permasalahan yang terjadi dalam pembelajaran dan menciptakan pembelajaran yang menarik, upaya yang harus dilakukan guru adalah memilih model pembelajaran yang tepat sesuai dengan materi pembelajaran.Dengan model pembelajaran yang tepat diharapkan mampu meningkatkan aktivitas peserta didik dalam belajar sehingga hasil belajarnya pun dapat ditingkatkan. Berdasarkan hasil penelitian yang dilakukan oleh Febriana (2011: 160), disimpulkan bahwa penerapan model pembelajaran kooperatif tipe make a match dapat meningkatkan aktivitas dan hasil belajar siswa. Hasil penelitian juga menyebutkan bahwa penerapan model pembelajaran kooperatif tipe make a match menunjukkan motivasi tinggi yang ditandai dengan ketepatan mencari pasangan, adanya kerjasama yang baik dalam mengerjakan tugas, keberanian dalam mempresentasikan hasil, berargumentasi maupun bertanya (Wijanarko, 2017)(Maulandhiyani et al., 2019). Penerapan model ini membutuhkan pengaturan waktu yang cermat untuk menghidari kebosanan peserta didik dalam belajar.

Salah satu model pembelajaran yang dapat meningkatkan aktivitas dan hasil belajar peserta didik adalah menggunkan model pembelajaran kooperatif (Cooperative Learning) dengan teknik make a match dengan media kartu. Dimana model make a match adalah model pembelajaran yang digunakan untuk memberikan konsep pemahaman materi 
yang sulit pada peserta didik serta dapat digunakan untuk mengetahui sejauh mana pengetahuan dan kemampuan peserta didik dari materi tersebut. Hal ini Kelebihan model pembelajaran kooperatif tipe make a match adalah sebagai berikut : 1) Dapat meningkatkan aktivitas belajar siswa, baik secara kognitif maupun fisik. 2) Karna ada unsur permainan, metode ini menyenangkan. 3) Meningkatkan pemahaman siswa terhadap materi yang dipelajari dan dapat meningkatkan motivasi belajar siswa. 4) Efektif sebagai sarana melatih keberanian siswa untuk tampil presentasi. Model pembelajaran ini juga dapat melatih siswa untuk mengungkapkan ide atau gagasan matematika yang ia miliki kepada temannya (Hardini, 2020).

Dari permasalahan tersebut, dalam pembelajaran matematika mencoba menerapkan model pembelajaran yang bervariasi, dimana model pembelajaran yang akan diterapkan peneliti dengan menggunakan model pembelajaran untuk meningkatkan hasil belajar peserta didik yaitu dengan menerapkan model pembelajaran kooperatif tipe Make A Match. Tujuan penelitian untuk mengetahui pengaruh model pembelajaran Make a Match terhadap hasil belajar matematika siswa.

\section{B. METODE PENELITIAN}

Jenis penelitian ini adalah penelitian Quasi eksperimen dengan rancangan posttest only. Sampel terdiri dari dua kelompok yang mana kelompok pertama yaitu kelas eksperimen diberi perlakuan berupa model make a match dan kelompok kedua yaitu kelas kontrol tidak diberi perlakuan diajarkan langsung oleh guru. Dalam penelitian ini yang menjadi pupulasi adalah seluruh peserta didik kelas VII SMP N 19 Mataram yang terdiri dari enam kelas yaitu Kelas VII A, Kelas VII B, Kelas VII C, Kelas VII D, Kelas VII E dan Kelas VII F. Sedangkan Sampel dalam penelitian ini yaitu kelas VII B sebagai kelas kontrol sebanyak 31 peserta didik dan kelas VII D sebagai kelas eksperimen sebanyak 30 peserta didik. Teknik pengumpulan data dalam penelitian ini dilakukan dengan cara tes dan lembar observasi. Teknik Analisis Data dengan Uji Hipotesis dan Uji analisis data observasi.

\section{HASIL DAN PEMBAHASAN}

Berdasarkan penelitian ini dilakukan di SMP N 19 Mataram dan sampel yang digunakan pada penelitian ini yaitu kelas VII B sebagai kelas kontrol diajarkan dengan metode konvesional yang diajakan oleh guru, sedangkan kelas VII D sebagai kelas eksperiment diajarkan dengan model make a match. Adapun penemuan peneliti dikelas VII D adalah sebagai berikut:

1. Terdapat kelemahan baik dari guru dan siswa sebagai berikut

a. terdapat siswa masih kurang memehami langkah - langkah model pembelajara make a match karena model ini tidak dipersiapkan dengan baik, sehingga banyak waktu yang terbuang.

b. Beberapa siswa masih terlihat kurang aktif dalam mencari pasangan kartu soal dan jawaban maupun saat diskusi, karena guru merasa lelah untuk mengarahkan siswa 
dengan baik dan guru masing kurang menekankan siswa adanya persaingan atau tim/kelompok pasangan.

c. Sebagian siswa yang malu bila menemukan pasangan dengan lawan jenisnya. Jadi hal ini di menjelaskan kelemahan modelmake a match.

a. Jika strategi ini tidak dipersiapkan dengan baik, akan banyak waktu yang terbuang.

b. Jika guru tidak mengarahkan siswa engan baik, akan banyak siswa kurang memperhatikan pada saat presentasi pasangan.

c. Pada awal - awal penerapan metode banyak siswa yang akan malu berpasangan dengan lawan jenisnya.

Adapun hasil tes belajar berupa posttest. Dari data posttest tersebut diperoleh nilai rata - rata kelas kontrol (VII B) adalah 73,8, sedangkan nilai rata - rata kelas eksperiment (VII D) adalah 76,7. Selanjutnya dilakukan uji homogenitas untuk kelas kontrol dan eksperiment.Berdasarkan hasil perhitungan diperoleh bahwa data kedua kelas memiliki varians yang homogen.Begitu pula uji normalitas diperoleh data kedua kelas adalah berdistribusi normal. Pada uji hipotesis diperoleh $t_{\text {hitung }}=-1,688$ dan $t_{\text {tabel }}=1,645$ maka $H_{0}$ ditolak dan $H_{a}$ diterima. Hal ini menunjukkan bahwa ada perbedaan hasil belajar antara siswa yang diajar dengan menggunakan model make a match dengan siswa yang diajar dengan metode ceramah atau tanya jawab. Dimana hasil belajar siswa kelas eksperiment lebih baik dari hasil belajar kelas kontrol.

Pembelajaran kelas eksperiment dengan model make a match lebih menekan pembelajaran metematika lebih bisa dinikmati siswa dengan penuh semangat. Model make a match bertujuan dalam suatu proses pembelajaran untuk siswa, yaitu meningkatkan partisipasi siswa, meningkatkan motivasi dan minat belajar, meningkatkan daya ingat dan meningkatkan rasa kebersamaan yang sebelumnya menakutkan jadi menyenangkan. Jadi, berdasarkan uraian tersebut dapat disimpulkan bahwa model make a match di rasakan efektif dalam meningkatkan hasil belajar matematika siswa kelas VII SMPN 19 Mataram.

\section{SIMPULAN DAN SARAN}

Berdasarkan hasil penelitian yang berjudul "Pengaruh model pembelajaran make a match terhadap hasil belajar matematika pada materi Statistika kelas VII SMP N 19 Mataram" dapat disimpulkan bahwa berdasarkan hasil perhitungan uji perbedaan dua rata - rata diperoleh data bahwa pada taraf signifikan 5\% $t_{\text {hitung }}>t_{\text {tabel }}=-1,688>$ 1,645 artinya ada pengaruh model pembelajaran make a match terhadap hasil belajar siswa pada materi statistika kelas VII SMP N 19 Mataram.

Berdasarkan hasil penelitian yang telah dilakukan maka peneliti mengajukan beberapa saran antara lain 1) Kepada sekolah dan pihak pengajar khususnya, hendaknya lebih selektif dalam memilih model pembelajaran yang tepat untuk meningkatkan hasil belajar siswa; 2) Guru hendaknya membuat perencanaan yang matang dalam memilih materi dan pengalokasian waktu terhadap model pembelajaran yang akan diterapkan dalam proses belajar mengajar. 


\section{REFERENSI}

Aini, B. O., Ayu, K. C., \& Siswati, S. (2019). Pengembangan Game Puzzle Sebagai Edugame Berbasis Android Untuk Meningkatkan Kemampuan Berpikir Matematika Siswa SD. JTAM / Jurnal Teori Dan Aplikasi Matematika, 3(1), 74. https://doi.org/10.31764/jtam.v3i1.768

Alawiyah, F. (2017). Standar Nasional Pendidikan Dasar dan Menengah. Aspirasi, 8(1), 81-92.

Arta Diantoro, S. B., Mahsup, M., \& Pramita, D. (2019). Penerapan Model Pembelajaran Kooperatif Tipe Two Stay Two Stray (TSTS) Dalam Meningkatkan Hasil Belajar Bentuk Aljabar Siswa Kelas VII SMP. Paedagoria / FKIP UMMat, 10(1), 01. https://doi.org/10.31764/paedagoria.v10i1.811

Budi, M. (2012). Pemanfaatan Teknologi Informasi Dan Komunikasi Untuk Meningkatkan Kualitas Pembelajaran Matematika. Jurusan Pendidikan Matematika FKIP, 1-19.

Eka Fitriani, M. M. (2018). Pengaruh Pembelajaran Kooperatif Tipe Jigsaw Untuk Meningkatkan Pemahaman. JUSTEK: JURNAL SAINS DAN TEKNOLOGI, 1(2), 1-8. https://doi.org/https://doi.org/10.31764/justek.v1i2.3541

Habe, H., \& Ahiruddin, A. (2017). Sistem Pendidikan Nasional. Ekombis Sains: Jurnal Ekonomi, Keuangan Dan Bisnis, 2(1), 39-45. https://doi.org/10.24967/ekombis.v2i1.48

Hardini, A. T. A. (2020). Mewujudkan Sekolah Peduli dan Berbudaya Lingkungan Menggunakan Model Make A Match. Publikasi Pendidikan, 10(2), 88. https://doi.org/10.26858/publikan.v10i2.10712

Kabunggul, Y., Pramita, D., Mandailina, V., Abdillah, Mahsup, \& Sirajuddin. (2020). Meningkatkan Motivasi Dan Hasil Belajar Siswa Melalui Penerapan Model Pembelajaran Team Game Tournament Berbantuan Media .... Jurnal Pendidikan Karakter, 3(2), 3-6.

Mahsup, \& Abdillah, A. (2019). Penerapan Pembelajaran Metode Diskusi Untuk Meningkatkan Hasil Belajar Matematika Mahasiswa Pada Materi Determinan. Jurnal Ulul Albab, 23(1), 33. https://doi.org/10.31764/jua.v23i1.643

Mahsup, \& Anwar, Y. S. (2020). Development of structured modules to improve the mathematical understanding of the circle concept in class VIII Mataram 17 junior high school. Journal of Physics: Conference Series. https://doi.org/10.1088/1742$6596 / 1465 / 1 / 012074$

Mahsup, M. (2018). Analisis Kesulitan Dalam Memahami Kemampuan Verbal Dalam Membuat Model Matematika Program Linear. Jurnal Ulul Albab. https://doi.org/10.31764/jua.v22i2.594

Mahsup, M., \& Anwar, Y. S. (2017). Sosialisasi Media Pita Bilangan Matematika Siswa Sekolah Dasar Desa Gelangsar Lombok Barat. JMM (Jurnal Masyarakat Mandiri). https://doi.org/10.31764/jmm.v1i1.10

Mahsup, M., \& Anwar, Y. S. (2018). Pengaruh Metode Stad Terhadap Hasil Belajar Matematika Mahasiswa. Jurnal Ulul Albab. https://doi.org/10.31764/jua.v22i1.584

Mahsup, M., Ibrahim, I., Muhardini, S., Nurjannah, N., \& Fitriani, E. (2020). Peningkatan Hasil Belajar Mahasiswa Melalui Model Pembelajaran Tutor Sebaya. Jurnal Kependidikan: Jurnal Hasil Penelitian Dan Kajian Kepustakaan Di Bidang Pendidikan, Pengajaran Dan Pembelajaran. https://doi.org/10.33394/jk.v6i3.2673

Mahsup, M., Islahudin, I., \& Anwar, Y. S. (2018). Pelatihan Penggunaan Media Pembelajaran Untuk Meningkatkan Pemahaman Dalam Menentukan Volume Bangun Ruang Bagi Siswa Sekolah Dasar. Selaparang Jurnal Pengabdian Masyarakat Berkemajuan. https://doi.org/10.31764/jpmb.v2i1.560

Mandailina, V., \& Mahsup, M. (2018). Efektivitas Pembelajaran Matematika dengan Metode Thinking Aloud Pair Problem Solving (TAPPS) Terhadap Hasil Belajar Siswa Pokok Bahasan Kubus dan Balok Kelas VIII SMP/MTs. JTAM / Jurnal Teori Dan Aplikasi Matematika. https://doi.org/10.31764/jtam.v2i2.717

Mandailina, V., Saddam, S., Ibrahim, M., \& Syaharuddin, S. (2019). UTAUT: Analysis of Usage Level of Android Applications as Learning Media in Indonesian Educational Institutions. IJECA (International Journal of Education and Curriculum Application), 2(3), 16. 
https://doi.org/10.31764/ijeca.v2i3.2080

Mandalina, V., Syaharuddin, Firdaus, M., Abdillah, Pramita, D., \& Negara, H. R. P. (2019). Math mobile learning app as an interactive multimedia learning mathematics. International Journal of Scientific and Technology Research, 8(10).

Maulandhiyani, W. T., Mulyana, E., \& Azizah, D. N. (2019). Penerapan Model Pembelajaran Make A Match Untuk Meningkatkan Hasil Belajar Siswa. Edusentris, 5(2), 114. https://doi.org/10.17509/edusentris.v5i2.298

Muhardini, S., Rahman, N., Mahsup, M., Sudarwo, R., Anam, K., \& Fujiaturrahman, S. (2020). Pengembangan Media Pembelajaran Box Nusantara untuk Membentuk Kemampuan Memahami Konsep Tematik pada Siswa Sekolah Dasar. Jurnal Kependidikan: Jurnal Hasil Penelitian Dan Kajian Kepustakaan Di Bidang Pendidikan, Pengajaran Dan Pembelajaran. https://doi.org/10.33394/jk.v6i2.2612

Rahmatin, N., Pramita, D., Sirajuddin, S., \& Mahsup, M. (2019). Pengembangan Modul Pembelajaran Bangun Ruang Dengan Metode Creative Problem Solving (CPS) Pada Siswa Kelas VIII SMP. JTAM / Jurnal Teori Dan Aplikasi Matematika. https://doi.org/10.31764/jtam.v3i1.760

Sintayana Muhardini, Sukron Fujiaturrahman, M. (2018). Pengembangan Media Pembelajaran Tematik Sd Berbasis Buletin Board Display. Prosiding Seminar Nasional Pendidik Dan Pengembang Pendidikan Indonesia.

Sukri, A., \& Purwanti, E. (2016). Meningkatkan Hasil Belajar Siswa Melalui Brain Gym. Jurnal Edukasi Matematika Dan Sains, 1(1), 50. https://doi.org/10.25273/jems.v1i1.778

Wijanarko, Y. (2017). Model Pembelajaran Make A Match Untuk Pembelajaran Ipa Yang Menyenangkan. Taman Cendekia: Jurnal Pendidikan Ke-SD-An, 1(1), 52. https://doi.org/10.30738/tc.v1i1.1579

Yusup, A. A. (2017). Meningkatkan hasil belajar matematika. Formatif : Jurnal Ilmiah Pendidikan MIPA, 7(2), 124-129. 